\title{
First-year Project-Based Engineering: Secret Weapon for Student Success
}

\section{Prof. Michael E. Pelletier, Northern Essex Community College}

Pelletier is an adjunct instructor and professor emeritus of Computer Technology \& Engineering at Northern Essex Community College. He holds a B.E.E. from Villanova University, a M.S.E.E. from Northeastern University and completed additional graduate work in Computer Engineering at Northeastern University.

Prof. Linda A. Desjardins, Northern Essex Community College

Prof. Paul Chanley, Northern Essex Community College

Chanley is program coordinator of Engineering Science \& Electronic Technology, Mathematics Faculty Member and Full Professor at Northern Essex Community College.

Prof. Lori Heymans, Northern Essex Community College 


\title{
First-year Project-Based Engineering: The Secret to Student Success
}

\begin{abstract}
This paper describes a project-based first-year introductory course at a community college which emphasizes working in teams on hands-on projects that require using EXCEL and MATLAB. Assignments involve graphing data for Ohm's Law and the speed of sound in air, distance measuring using ultrasound, programming in MATLAB to control the movement of a steppermotor rotor and programming in MATLAB to analyze and identify the visible spectra of several translucent materials. Students are required to make presentations of the projects and the results obtained.

To document student success, data on student achievement in the course was collected for seven offerings of the course over three semesters: fall of 2011, spring of 2012, and fall of 2012. In addition, an outside evaluator used a self-survey to assess pre- and post- student attitudes toward certain skills thought to be enhanced by participation in the course.
\end{abstract}

\section{Course beginnings}

Recognizing that project-based learning is a very valuable way to introduce beginning students to engineering ${ }^{1-4}$, Professor Stephen McKnight of Northeastern University offered a two-week professional development workshop for community college instructors in June, 2010. Attending that workshop were faculty members from three Massachusetts community colleges: Northern Essex Community College (NECC), Middlesex Community College, and Massachusetts Bay Community College. Over a span of two weeks, the community college faculty worked in teams to complete the same hands-on projects that first-year engineering students at Northeastern University completed in a semester. The workshop featured programming in MATLAB and $\mathrm{C}++$. At the end of the workshop the community college faculty selected certain projects as most appropriate for their institutions. Subsequently, Whittier Regional Technical School, a local technical high school with a machine shop and an electronics fabrication shop, agreed to build the needed equipment using diagrams, parts and advice from Northeastern University.

In the fall of 2010, the paperwork for a new course entitled Engineering Essentials and Design (EED) was submitted to the Academic Affairs Committee of NECC by engineering faculty from NECC who had attended the two-week workshop. In the spring of 2010, the Academic Affairs Committee approved EED as a required course for Engineering Science and added EED to the college catalog as EST104.

A second two-week professional development workshop for community college instructors in June, 2011 was used to further the skills of the community college instructors in MATLAB and further adapt the projects to the community college environment. Development of EST104 as a transferable, project-based, engineering course, emphasizing computer programming in MATLAB continued throughout the summer. Further details on the work done developing this course and a similar course at Mass Bay CC can be found in a paper presented at the 2012 ASEE Annual Conference, entitled "A First-Year 'Introduction to Engineering' Course at a Community College Using Hands-On MATLAB Experiment Control.", 


\section{The first year of Engineering Essentials and Design}

Two sections of Engineering Essentials and Design were taught in the fall 2011 semester and another two sections were taught in the spring of 2012 at NECC by an adjunct engineering instructor, Professor Michael Pelletier, who is the principal author of this paper. Each section had an enrollment limited to 20 students.

- The course grade was determined solely by assignments submitted and several presentations made; no tests were administered.

- Assignments were completed in class by teams, but submitted by each individual.

- All assignments were submitted electronically, on-line through Blackboard. No paper copies of submissions were allowed.

- Assignments were due one week after each meeting but no penalty was assessed for late submissions.

- The instructor often waited two weeks after assignments were submitted to grade them.

- Graded assignments could be revised and resubmitted at any time for re-grading.

The initial offering of EST104 was one section on Fridays from 10 am to 1:50 pm. When this section reached capacity in one week, a second section was added on Thursday morning from 8 am $-11: 50 \mathrm{am}$. During the fall of 2011, Professor McKnight came to the community college and met with the community college adjunct instructor on Mondays to cooperatively develop course materials and handouts appropriate to the audience at the community college and adapt the hands-on projects to the newly obtained equipment which had been fabricated at a local technical high school using samples, schematics and materials supplied by the university. During most of that first semester, the course materials were being delivered "just in time" for student use.

\section{EST104 Topical Syllabus}
A. Engineering as a Career
B. Ethics
C. Engineering Design and Teamwork
D. Engineering Communication
E. EXCEL - Workbooks \& Graphs
F. MATLAB programming - script files, functions, input/output, plotting, logic and conditionals, logic and relational operators, conditional statements, for loops, while loops.

\section{EST104 Schedule of topics for fall 2011}

- Week 1-5 EXCEL with applications to Ohm's Law and the Speed of Sound in air.

- Week 6 Flowcharting and Procedural Programming

- Week 7-10 MATLAB - Programming a Stepper Motor in MATLAB

- Week 11-13 Spectroscopic ID of colored filters using a spectrometer and MATLAB

- Week 14 Spectroscopic ID of oils using visible light, a spectrometer, and MATLAB

- Week 15 Final Presentations 


\section{Results for EST104 for fall 2011}

EST104-R8 for fall 2011 met on Thursdays from 8 until 11:50 am. This section had seven sophomores and thirteen freshmen enrolled initially. Seventeen students listed Engineering Science as a major; one student listed Computer and Information Sciences as a major; one student listed Electronic Technology as a major and one student was Undeclared. Sixteen of the students received a non-zero grade at the end of the course.

Overall scores for the entire semester's work which were achieved by the students in EST104-R8 are shown in Figure 1.

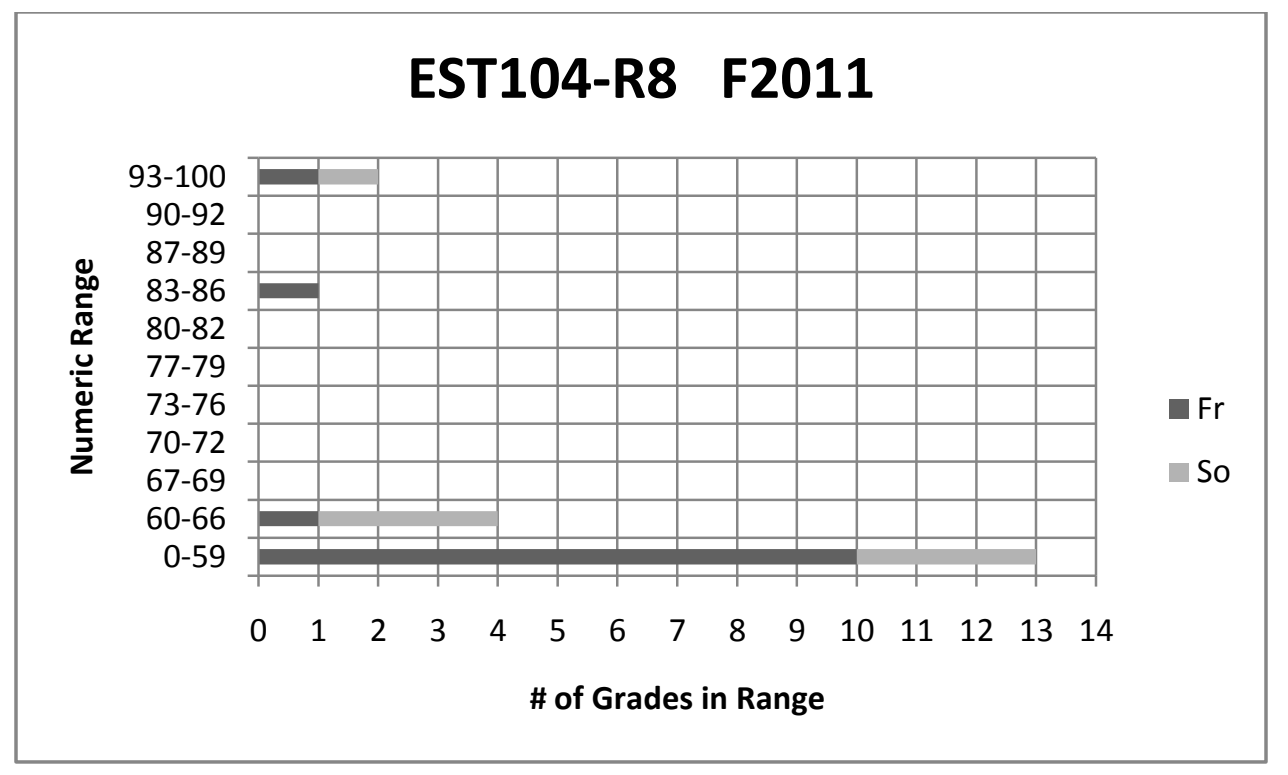

Figure 1 Numerical averages for Thursday section of EST104 - fall 2011

A second section of Engineering Essentials and Design with the alphanumeric designation EST104-F10 was offered on Fridays from $10 \mathrm{am}$ - 1:50 pm. EST104-F10 for fall 2011 had nine sophomores and six freshmen complete the course. All fifteen students listed Engineering Science as their major.

Figure 2 shows the semester-long distribution of scores within the various numeric ranges for the Friday section. 


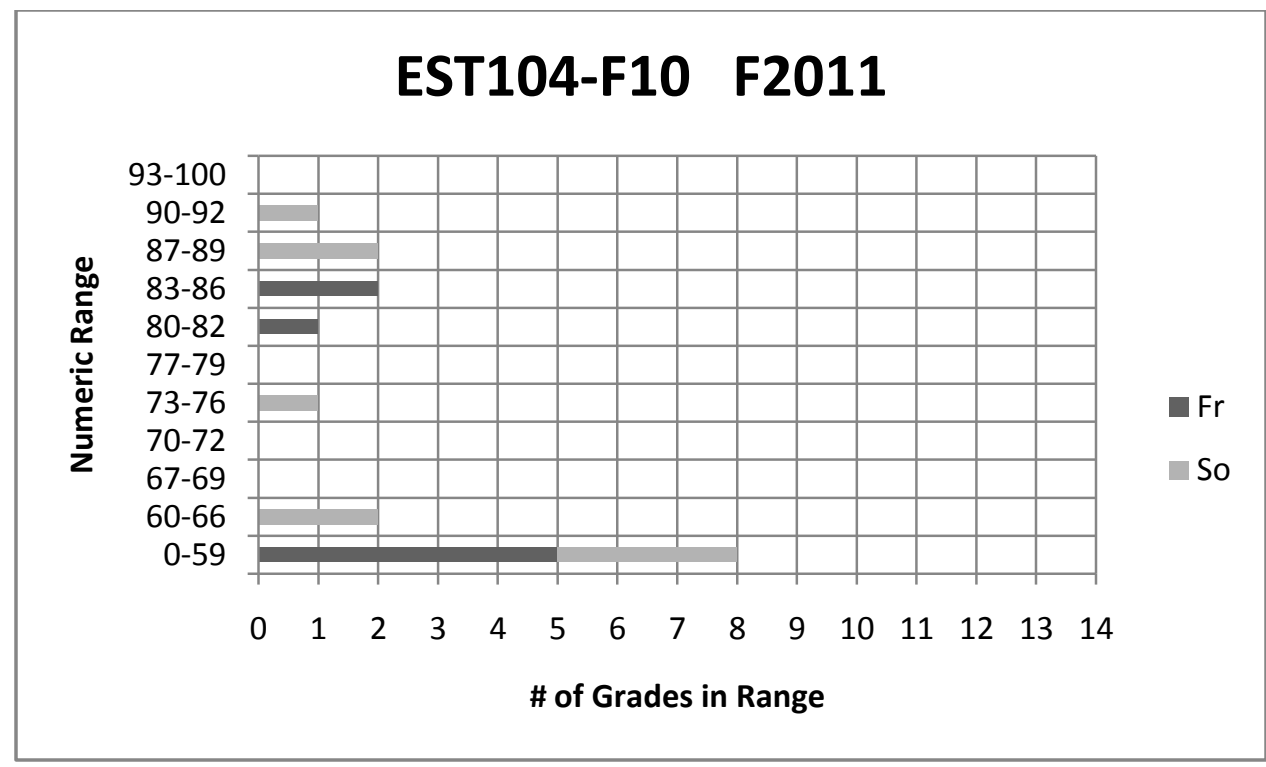

Figure 2 Numerical averages for Friday section of EST104 - fall 2011

Using the data behind the graphs in Figure 1 and Figure 2 and calculating the average scores for freshmen and sophomores, Table 1 was developed to compare the scores for the freshmen and sophomores by section and combined. It is interesting that across both sections, the freshmen did slightly better than the sophomores.

\begin{tabular}{|l|l|l|l|l|l|l|}
\hline \multirow{2}{*}{$\begin{array}{c}\text { Fall } \\
2011\end{array}$} & \multicolumn{2}{|c|}{ EST104-R8 } & \multicolumn{2}{c|}{ EST104-F10 } & \multicolumn{2}{c|}{ Combined } \\
\hline & $\begin{array}{l}\text { Average } \\
\text { Score }\end{array}$ & $\begin{array}{l}\text { Sample } \\
\text { Size }\end{array}$ & $\begin{array}{l}\text { Average } \\
\text { Score }\end{array}$ & $\begin{array}{l}\text { Sample } \\
\text { Size }\end{array}$ & $\begin{array}{l}\text { Average } \\
\text { Score }\end{array}$ & $\begin{array}{l}\text { Sample } \\
\text { Size }\end{array}$ \\
\hline Soph & 57.1 & 7 & 62.28 & 9 & 60.0 & 16 \\
\hline Fr & 58.5 & 9 & 67.58 & 6 & 62.1 & 15 \\
\hline
\end{tabular}

Table 1 Averages of student scores for fall of 2011

The most sophisticated project in the course was to combine a program providing automatic identification (ID) of different oils with a program to control the stepper motor and rotate the vials of oil into and out of a sample chamber. Only a single team of three students attempted this project and succeeded at it.

In doing just the ID of different oils, only five of the sixteen students in Thursday's section R8 were able to get full credit. In Friday's section F10, nine students received full credit and 2 received partial credit.

The large number of sophomore students in what was designed to be a first-year course reflects the encouragement given to sophomore students to take this new course with its promised transferability to the university. It was interesting that the sophomore students did not outperform the freshmen; but instead, did slightly worse. 


\section{The Second Semester of Engineering Essentials and Design}

Two sections of EST104 were offered in the spring of 2012: one on Friday from 10 am - 1:50 pm and a second section on Thursday from $2 \mathrm{pm}-4: 50 \mathrm{pm}$ with an additional $4^{\text {th }}$ hour on Friday from 2- $3 \mathrm{pm}$. This fourth hour was necessary to satisfy college requirements for sufficient time in the classroom/lab but proved of little interest to the students, most of whom had other commitments, especially work, on Friday afternoon. The fourth hour was not possible on Thursday because the one classroom/lab with MATLAB and the equipment needed for the projects was not available on Thursdays, except for 2-5. An additional hour on Monday, Tuesday, or Wednesday was not possible because of Professor Pelletier's schedule from January through the end of March.

Since Professor McKnight was not available in the spring, Professor Pelletier taught the two sections of the course alone and continued to revise the course materials throughout the semester.

EST104 Schedule of Topics for spring 2012 (unchanged from fall 2011)

- Week 1-5 EXCEL with applications to Ohm's Law and the Speed of Sound in air.

- Week 6 Flowcharting and Procedural Programming

- Week 7-10 MATLAB - Programming a Stepper Motor in MATLAB

- Week 11-13 Spectroscopic ID of colored filters using visible light, a spectrometer, and MATLAB

- Week 14 Spectroscopic ID of oils using visible light, a spectrometer, and MATLAB

- Week 15 Final Presentation

\section{Results for EST104 for spring 2012}

Section EST104-RF2 for spring of 2012 had four sophomores and fifteen freshmen enrolled. Seventeen students listed Engineering Science as a major; one listed Electronic Technology as a major and one was Undeclared.

Overall scores for the entire semester's work which were achieved by the students in EST104RF2 are shown in Figure 3. 


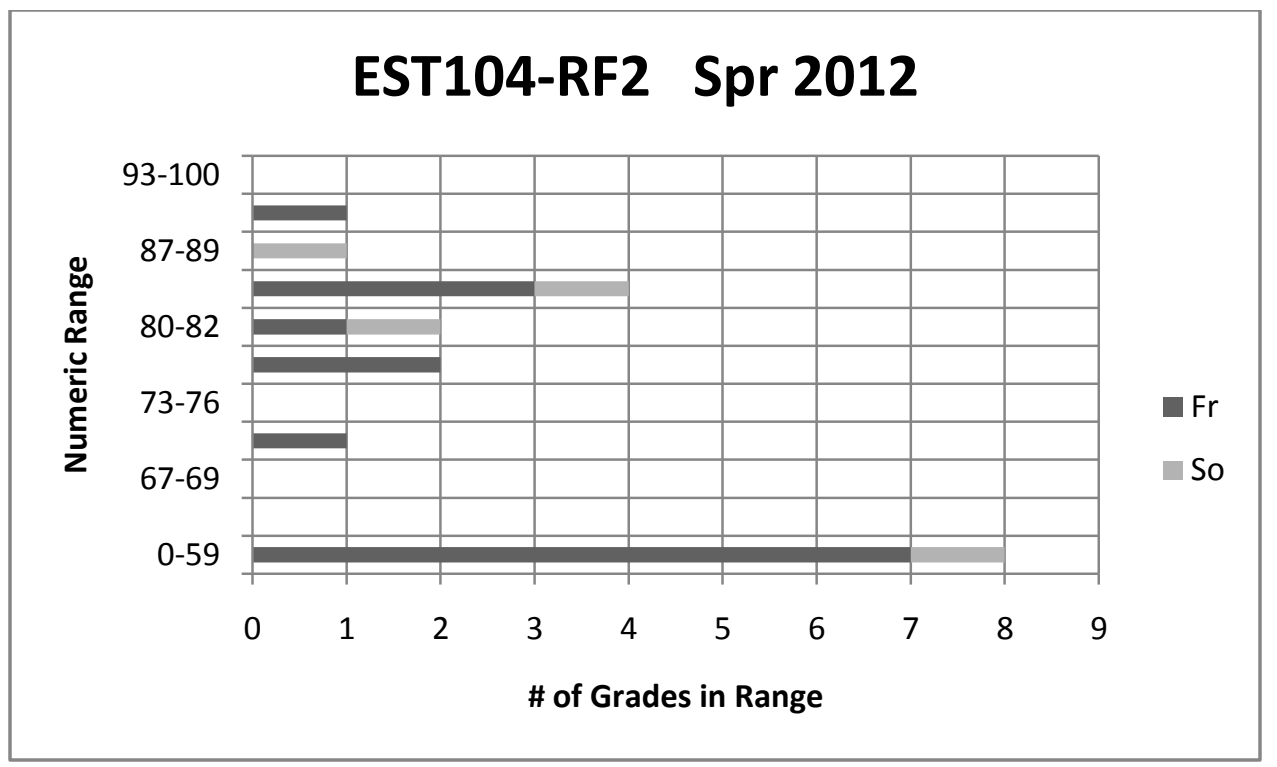

Figure 3 Numerical averages for Thursday section of EST104 - spring 2012

The other section for the spring of 2012, EST104-F10, had four sophomores and fourteen freshmen enrolled. All eighteen students listed Engineering Science as a major.

The semester-long distribution of scores within the various numeric ranges for the Friday section is shown in Figure 4.

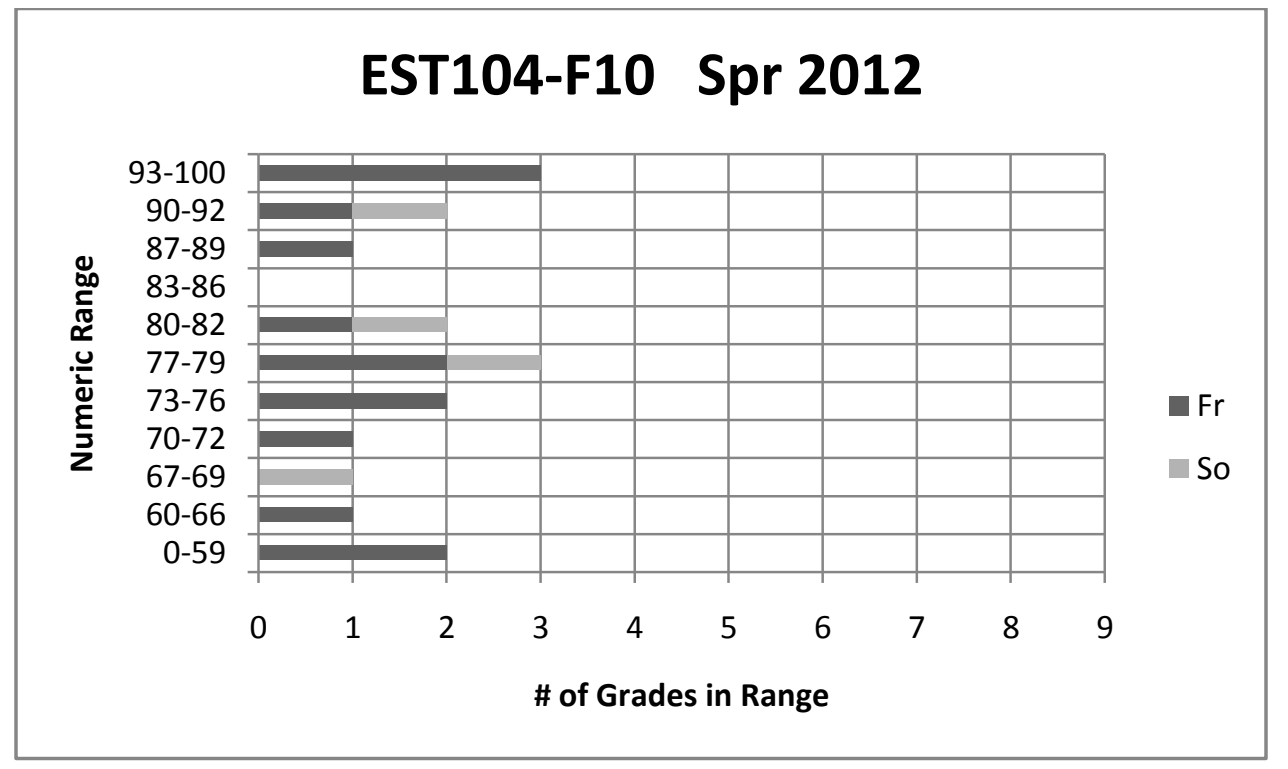

Figure 4 Numerical averages for Friday section of EST104 - spring 2012

Using the data behind the graphs in Figure 3 and Figure 4 and calculating the average scores for freshmen and sophomores, Table 2 was developed to compare the scores for the two groups. Unlike the previous semester (fall of 2011), in the spring of 2012 the sophomores outperformed the freshmen across both sections. 
It is interesting that the students in the Friday section fared better than those enrolled in the Thursday section. The improvement of the scores of the freshmen from Friday's section over that of the freshmen from Thursday's section is striking and it is higher than the increase of the scores of the sophomores. However, given the small number of sophomores and the fact that students self-selected into the two sections based on which would best fit into their schedules, postulating reasons for the observed differences is problematical.

\begin{tabular}{|c|c|c|c|c|c|c|}
\hline \multirow[t]{2}{*}{$\begin{array}{l}\text { Spring } \\
2012\end{array}$} & \multicolumn{2}{|c|}{ EST104-RF2 } & \multicolumn{2}{|c|}{ EST104-F10 } & \multicolumn{2}{|c|}{ Combined } \\
\hline & $\begin{array}{l}\text { Average } \\
\text { Score }\end{array}$ & $\begin{array}{l}\text { Sample } \\
\text { Size }\end{array}$ & $\begin{array}{l}\text { Average } \\
\text { Score }\end{array}$ & $\begin{array}{l}\text { Sample } \\
\text { Size }\end{array}$ & $\begin{array}{l}\text { Average } \\
\text { Score }\end{array}$ & $\begin{array}{l}\text { Sample } \\
\text { Size }\end{array}$ \\
\hline Soph & 74.9 & 4 & 79.4 & 4 & 77.2 & 8 \\
\hline $\mathrm{Fr}$ & 55.4 & 15 & 74.5 & 14 & 64.6 & 29 \\
\hline
\end{tabular}

Table 2 Averages of student scores for spring of 2012

Despite the overall improvement in scores by both the freshmen and sophomores in the spring semester, only five students in the Thursday section (EST104-RF2) were able to complete Oil ID and none completed Auto Oil_ID which required combining Oil ID with programming the stepper-motor rotor to move the vials of oil through the sample chamber.

\section{Engineering Essentials and Design for fall of 2012}

During the summer of 2012, Professor Pelletier decided to modify his approach for the two sections of the EST104 course as follows:

- The course grade would still be determined by project work assignments submitted and the presentations delivered; no tests would be administered.

- All assignments would be submitted on-line through Blackboard.

- Assignments would be shown to the instructor during the class meeting for a preliminary non-graded assessment.

- Assignments would be due from each individual two to four days after the class meeting but no penalty would be assessed for late submissions.

- The instructor would grade assignments within two days after submission.

- Assignments could be resubmitted for re-grading until 24 hours before the next meeting.

\section{Why approach for fall 2012 was modified}

The goals of the planned fall 2012 modifications were to:

- Make the assessments of student submissions more formative instead of merely summative;

- Provide timely formative assessments to students;

- Improve the quality of student work submitted;

- Have students more positively self-assess their attitudes toward technical skills as measured by a survey instrument developed for the fall of 2011. 


\section{Change in plans for fall 2012}

For the third semester in a row, one section had been scheduled for Fridays from 10 am - 1:45 pm. A second section was scheduled for Thursdays from $1 \mathrm{pm}-4: 45 \mathrm{pm}$.

But in response to an increase in enrollments, in August of 2012 NECC, after conferring with Professor Pelletier, added a third section of EST104, scheduled for Wednesdays 9 am - 12:45 $\mathrm{pm}$ and assigned the new section to Professor Pelletier. This 50\% increase in the amount of assignments to be corrected spelled the doom of attempts by the course instructor to change the assessment of assignments from evaluative to formative.

\section{Introduction of Supplemental Instruction to EST104}

The Engineering Science Coordinator realized the nature of the challenge posed by the addition of a third section of EST104 and sought additional help for the adjunct instructor. In late August, Raytheon, a local employer in Andover, Massachusetts, provided funds to support Supplemental Instruction (SI) in the course.

At NECC, each course designated for Supplemental Instruction is assigned a Supplemental Instruction Leader. An SI Leader is a student who has taken the course before and received a grade of A or A-. Ideally, the SI Leader is identified before course registration and the time and day of the SI sessions are known to the students before they register for the course. (This was not the case at NECC for EST104 because SI was added long after registration had taken place in the spring.) The SI Leader attends all classes and labs and takes notes like all of the other students. Then the SI Leader conducts additional sessions outside of class for the students without the instructor present. Attendance at these sessions is optional.

Because of the problem-based, hands-on nature of EST104 at NECC, these optional sessions take place in the one classroom/lab which has both MATLAB and the required lab equipment such as stepper-motor rotors, control boxes, DAQs, and spectrometers.

During the first week of September, six potential SI Leaders (chosen from the best students who had completed EST104) were contacted; but only one SI Leader was identified initially. He was assigned to the Thursday section of the course and began holding SI sessions in the lab on Thursdays before the $1 \mathrm{pm}$ start of the Thursday section. Attendance at SI sessions was voluntary.

A second SI leader was identified during the third week of the class and he was assigned to both the Wednesday and Friday sections, but he was only available for two hours on Wednesday and two hours on Friday out of the four hours that each section met on those two days. In addition, this SI leader offered to host a weekly SI session on Friday afternoon, but this met with no success. At the end of November this SI leader suffered an ankle injury and was unable to finish out the semester.

In response to student suggestions from the spring 2012 semester to lessen the time spent on EXCEL and increase the time spent on MATLAB, a shift was made in the syllabus and EXCEL 
was used for graphing data only in weeks 1- 3. MATLAB was introduced in week 4 and was used exclusively throughout the rest of the semester.

\section{EST104 Schedule of Topics for fall 2012}

- Weeks 1-3 EXCEL with applications to Ohm's Law and the Speed of Sound in air.

- Week 4 Plotting graphs in EXCEL and MATLAB, algorithms, flowcharting and procedural programming.

- Week 5 Creating and saving functions and programs in MATLAB

- Weeks 6-8 Programming a Stepper Motor in MATLAB

- Weeks 9-11 MATLAB - Spectroscopic ID of colored filters using visible light, a spectrometer, and MATLAB

- Week 12 Thanksgiving Holiday (only Wed section met in Week 12)

- Week 13 Spectroscopic ID of oils using visible light, a spectrometer, and MATLAB

- Week 14 Combining Oil_ID with programming a stepper motor rotor

- Week 15 Final Presentation

\section{Results for EST104 for fall 2012}

During the fall of 2012, EST104-W9 had five sophomores and twelve freshmen enrolled at the end of the course. Eleven students listed Engineering Science as a major; two listed Electronic Technology as a major; two listed Liberal Arts; one student listed Computer-Aided Drafting and one was in General Studies.

The semester-long distribution of scores within the various numeric ranges for this Wednesday section is shown in Figure 5.

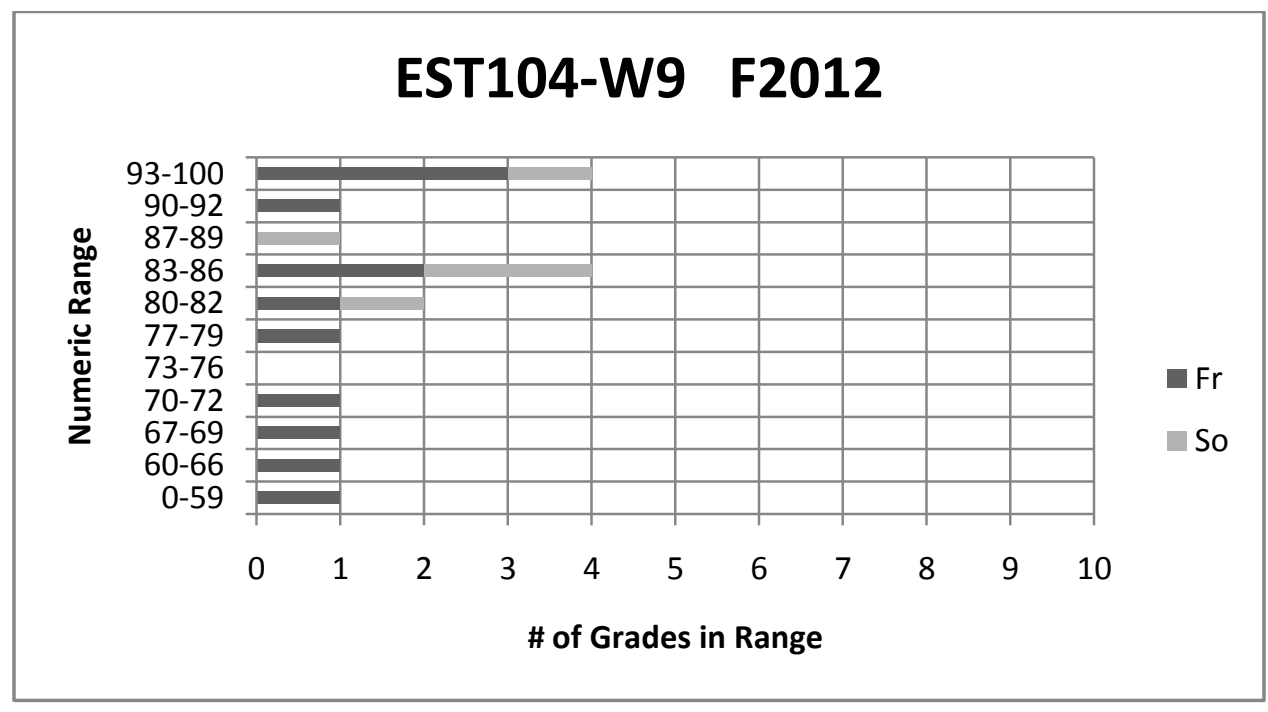

Figure 5 Numerical averages for Wednesday section of EST104 - fall 2012 
EST104-R1 which met on Thursday afternoon during the fall of 2012 had ten sophomores and ten freshmen enrolled. Nineteen students listed Engineering Science as a major and one listed Computer and Information Sciences as a major.

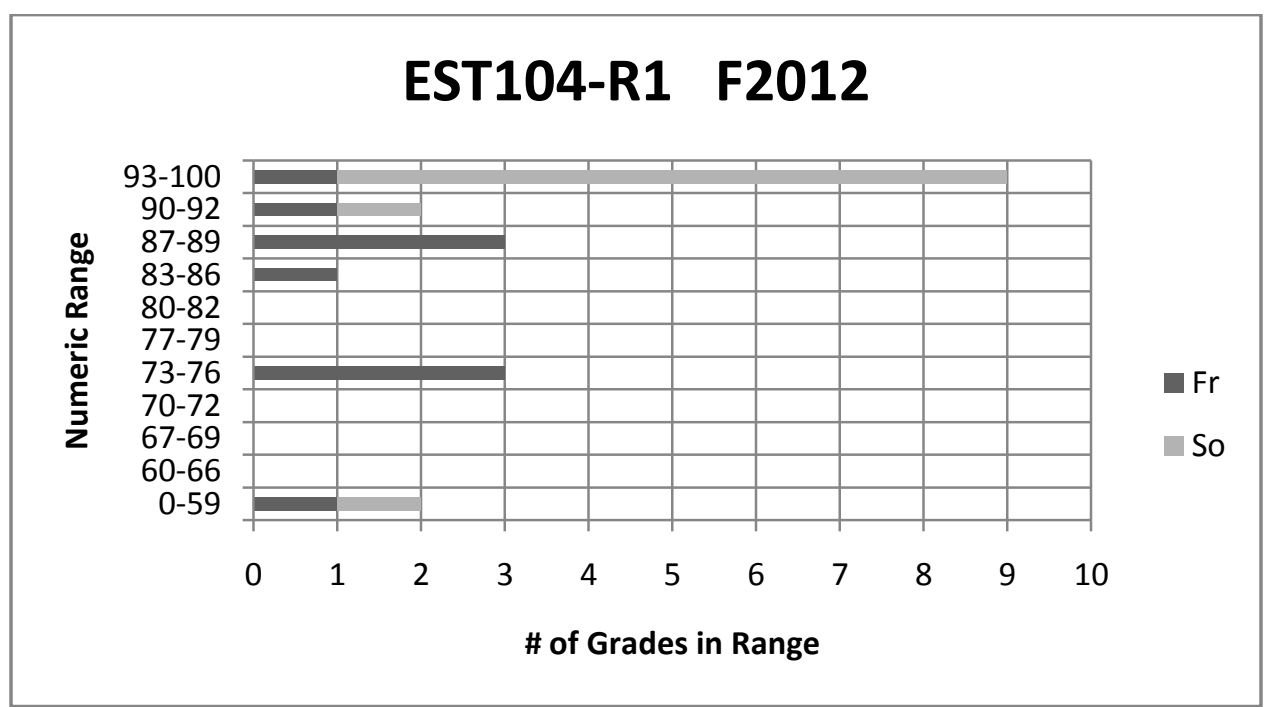

Figure 6 Numerical averages for Thursday section of EST104 - fall 2012

This Thursday section is notable for having all twenty students enrolled at the beginning of the course persist until the end of the course and for having eleven of the twenty students finish in the numeric range of 90-100. These eleven included nine of the ten sophomores enrolled. This section is also the only one with an SI leader for the entire semester.

The third section of Engineering Essentials and Design during the fall of 2012, EST104-F10, had six sophomores and thirteen freshmen enrolled. Eighteen students listed Engineering Science as a major and one listed Liberal Arts as a major.

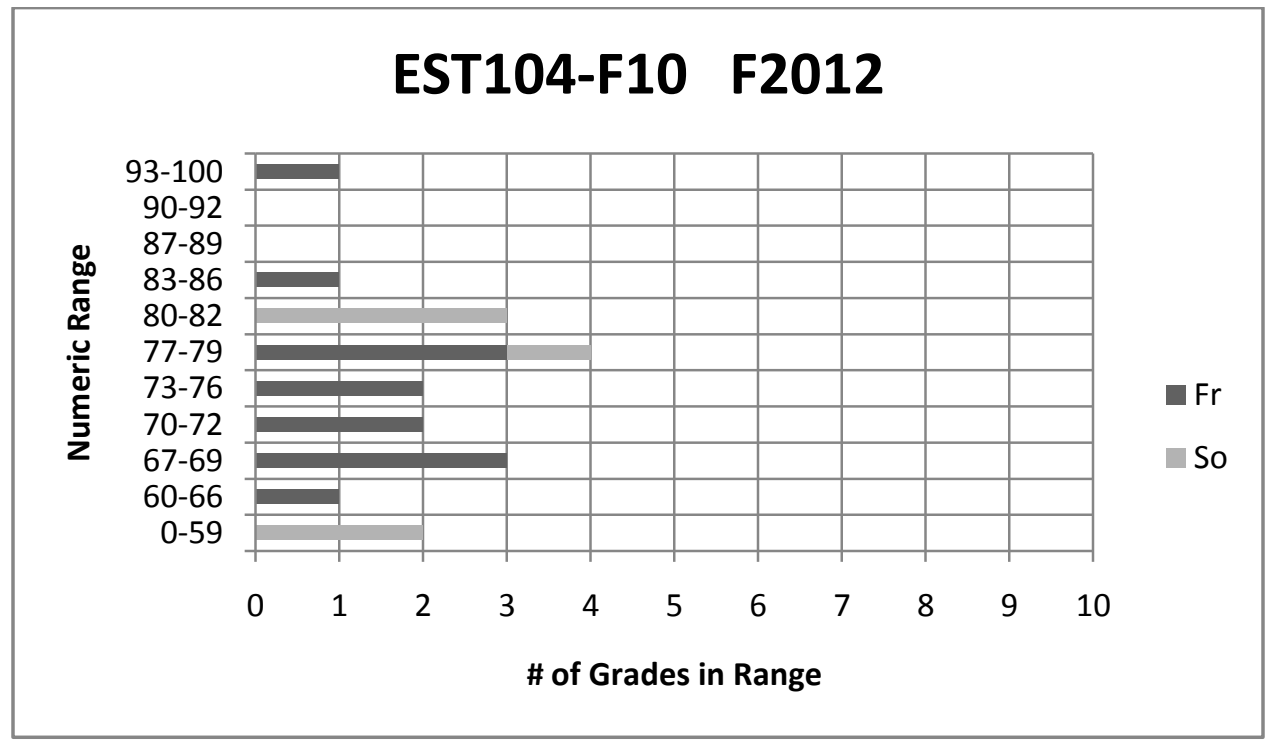

Figure 7 Numerical averages for Friday section of EST104 - fall 2012 
Using the data behind the graphs from Figure 5, Figure 6 and Figure 7 and calculating the average scores for freshmen and sophomores, Table 3 compares the scores across the three sections. In two out of three of the sections the sophomores outperformed the freshmen.

\begin{tabular}{|l|l|l|l|l|l|l|l|l|}
\hline $\begin{array}{l}\text { Fall } \\
2012\end{array}$ & \multicolumn{2}{|c|}{ EST104-W9 } & \multicolumn{2}{c|}{ EST104-R1 } & \multicolumn{2}{c|}{ EST104-F10 } & \multicolumn{2}{c|}{ Combined } \\
\hline & $\begin{array}{l}\text { Average } \\
\text { Score }\end{array}$ & $\begin{array}{l}\text { Sample } \\
\text { Size }\end{array}$ & $\begin{array}{l}\text { Average } \\
\text { Score }\end{array}$ & $\begin{array}{l}\text { Sample } \\
\text { Size }\end{array}$ & $\begin{array}{l}\text { Average } \\
\text { Score }\end{array}$ & $\begin{array}{l}\text { Sample } \\
\text { Size }\end{array}$ & $\begin{array}{l}\text { Average } \\
\text { Score }\end{array}$ & $\begin{array}{l}\text { Sample } \\
\text { Size }\end{array}$ \\
\hline Soph & 87.6 & 5 & 86.9 & 10 & 61.4 & 6 & 79.8 & 21 \\
\hline Fr & 81.7 & 12 & 78.3 & 10 & 75.0 & 13 & 78.2 & 35 \\
\hline
\end{tabular}

Table 3 Averages of student scores for fall of 2012

\section{How to assess the effectiveness of the Engineering Essentials and Design course}

To measure the effectiveness of EST104 over the three semesters the authors looked at several different measures:

- The Course Completion Rate (CCR), defined as the percentage of grades within the range A-C (but not including C-), was calculated for the seven sections of EST104 and compared with the CCR of all EST courses and the CCR of all NECC courses.

- The percentages of students enrolled in EST104 who subsequently either earned a degree or left in good academic standing or are still enrolled at NECC, defined as the Success Rate, was calculated and is included in the Tables.

- Pre- and post-surveys of student attitudes were administered in the fall of 2011 and the spring of 2012 using an instrument designed by Dr. Paula Leventman, an outside evaluator from Northeastern University. These survey results were evaluated by Dr. Leventman. Student self-assessments of attitudes continue to be very positive and the hands-on activities remain very popular.

- Since assignments and maximum possible point totals have remained relatively stable across the three semesters, point distributions earned by students across the three semesters were compared earlier in this paper and show that student scores on the assignments continue to trend upward.

\section{Course Completion Rate}

When asked to measure the possible success of the EST104 course, Tom Fallon, the Director of Research and Development at NECC, calculated a Course Completion Rate (CCR) defined as the percentage of Grades (A-C), but not including C- for the seven sections of EST104 and compared the CCR for EST104 to the CCR of all the EST courses for Fall 2012 and the CCR for the total grades for all NECC courses. In an e-mail, Tom Fallon said, "As you can see, the CCR for EST104 is higher than that for all EST and all NECC grades.", 


\begin{tabular}{|l|r|r|r|}
\hline \multirow{2}{*}{} & \multicolumn{3}{|c|}{ Overall CCR } \\
& \multicolumn{3}{|c|}{ All Students } \\
\cline { 2 - 4 } & Total grades & Grades A- C & CCR\% \\
\hline $\begin{array}{l}\text { EST104 (7 } \\
\text { sections) }\end{array}$ & 135 & 102 & $75.6 \%$ \\
\hline & & & \\
\hline All EST - Fall 2012 & 172 & 122 & $70.9 \%$ \\
\hline & & & \\
\hline & & & \\
Total NECC grades & 20,521 & 14,729 & $71.8 \%$ \\
\hline
\end{tabular}

Table 4 Course Completion Rate (CCR) for all students

Table 4 compares the CCR (the percentage of Grades (A-C), but not including $\mathrm{C}$-) for three groups: 1) all of the students who received a grade in EST104 in any of the seven sections of the course from fall of 2011, spring of 2012, or fall of 2012; 2) all of the students who received a grade in an EST course taken during the fall of 2012; and all the students who received a grade at NECC in the fall of 2012. Both freshmen and sophomore students were included.

In the fall of 2012, EST courses included Engineering Essentials and Design, Engineering Design Graphics, Computer-Aided Drafting I, Computer-Aided Drafting II, Statics, and Engineering Circuit Analysis. Table 4 above shows that when all of the students, both freshmen and sophomores are combined, there is a higher CCR for EST104 than for all of the EST courses offered during the fall of 2012 and a higher CCR for EST104 than for all of the NECC courses combined.

\begin{tabular}{|c|c|c|c|c|c|c|}
\hline & \multicolumn{3}{|c|}{$\begin{array}{l}\text { Overall CCR } \\
\text { Only Freshmen }\end{array}$} & \multicolumn{3}{|c|}{$\begin{array}{l}\text { Overall CCR } \\
\text { Only Sophomores }\end{array}$} \\
\hline & Total grades & Grades A- C & CCR\% & Total grades & Grades A- C & CCR\% \\
\hline $\begin{array}{l}\text { EST104 (7 } \\
\text { sections) }\end{array}$ & 93 & 68 & $73.1 \%$ & 42 & 34 & $81.0 \%$ \\
\hline All EST - Fall 2012 & 62 & 38 & $61.3 \%$ & 110 & 84 & $76.4 \%$ \\
\hline Total NECC grades & 13,373 & 9,312 & $69.6 \%$ & 7,148 & 5,417 & $75.8 \%$ \\
\hline
\end{tabular}

Table 5 Course Completion Rate (CCR) by Freshmen/Sophomore status

Table 5 shows the CCR for freshmen and sophomores separately. At NECC, a student is considered a freshman if the accumulated earned credits are less than 30; a student is considered a sophomore if the accumulated earned credits are more than 30. Once again, there is a higher CCR for EST104 than for all of the EST courses offered in the fall of 2012 and a higher CCR for the seven sections of EST104 than for all of the NECC courses offered in the fall of 2012. 


\section{Persistence at NECC by Students Completing EST104}

In an attempt to gauge the effect on persistence at NECC of students completing EST104 Engineering Essentials and Design, the transcripts of all 131 students who had received a grade in EST104 during the first three semesters of its operation were examined and tables of data were constructed. As a measure of how many of those students had remained in Engineering Science or in whatever their major was at the time of enrolling in EST104,a Success Rate was calculated.

The Success Rate is the percentage of students from a given major receiving a letter grade in EST104 who subsequently received either an Associate's degree or a certificate from NECC or left NECC in Good Academic Standing but without a degree or who are still students and currently enrolled in courses at NECC during the Spring 2013 semester. Non-successful students were defined as those students receiving a letter grade in EST104 who subsequently left NECC on probation or left NECC under suspension.

The following tables, Table 6 , Table 7 , and Table 8 , show what happened to all of the students, grouped according to major, after they received a grade in EST104 during one of the three semesters. Also included in the table are the Success Rates for every major that had at least one student of that major enrolled in EST104.

In the tables, ES stands for Engineering Science, ET stands for Electronic Technology, and CIS stands for Computer Information Sciences. LA stands for Liberal Arts and Gen Studies stands for General Studies.

\begin{tabular}{|c|c|c|c|c|c|c|c|}
\hline \multicolumn{7}{|c|}{ Status (as of February, 2013) of all students receiving a grade in EST104 in Fall, 2011} & \multirow[t]{2}{*}{$\begin{array}{l}\text { Success } \\
\text { Rate }\end{array}$} \\
\hline Major & $\begin{array}{l}\text { Rcvd NECC } \\
\text { Degree }\end{array}$ & $\begin{array}{l}\text { Still } \\
\text { at } \\
\text { NECC }\end{array}$ & $\begin{array}{l}\text { Left NECC in } \\
\text { Good Standing }\end{array}$ & $\begin{array}{l}\text { Left NECC on } \\
\text { Probation }\end{array}$ & $\begin{array}{l}\text { Left NECC } \\
\text { Suspended }\end{array}$ & Total & \\
\hline ES & 4 & 19 & $\mathbf{5}$ & & & 28 & $100 \%$ \\
\hline ET & & & & & & 0 & \\
\hline CIS & & 1 & & & & 1 & $100 \%$ \\
\hline Unclassified & & & 1 & & 3 & 4 & $25 \%$ \\
\hline Business & & 1 & 1 & & & 2 & $100 \%$ \\
\hline Gen Studies & & 1 & & & & 1 & $100 \%$ \\
\hline LA & & 1 & & & & 1 & $100 \%$ \\
\hline Healthcare & & 0 & 0 & & & 0 & \\
\hline
\end{tabular}

Table 6 Persistence of EST104 students from Fall 2011 semester through February, 2013

The data presented in Table 6 shows that by February 2013, $100 \%$ of the students who were enrolled in a recognized major at NECC (even if it were not ES, ET, or CIS) either were still enrolled at NECC in their original major or had received a NECC degree or had left NECC without a degree but in good academic standing. The experience of the unclassified students was much different as three out of the four were subsequently academically suspended and no longer attend NECC. An examination of the transcripts of the three suspended students showed that each was so poorly prepared in Mathematics that they could not be formally accepted into the 
Engineering Science program, but were instead declared Unclassified and allowed by an advisor to enroll in EST104 anyway.

\begin{tabular}{|c|c|c|c|c|c|c|c|}
\hline \multicolumn{7}{|c|}{ Status (as of February, 2013) of students receiving grade in EST104 in Spring, 2012} & $\begin{array}{l}\text { Success } \\
\text { Rate }\end{array}$ \\
\hline Major & $\begin{array}{l}\text { Rcvd } \\
\text { NECC } \\
\text { Degree }\end{array}$ & $\begin{array}{l}\text { Still } \\
\text { at } \\
\text { NECC }\end{array}$ & $\begin{array}{l}\text { Left NECC in } \\
\text { Good Standing }\end{array}$ & $\begin{array}{l}\text { Left NECC on } \\
\text { Probation }\end{array}$ & $\begin{array}{l}\text { Left NECC } \\
\text { Suspended }\end{array}$ & Total & \\
\hline ES & 2 & 20 & 4 & 2 & 1 & 29 & $90 \%$ \\
\hline ET & 1 & & & & & 1 & $100 \%$ \\
\hline CIS & & 2 & & & & 2 & $100 \%$ \\
\hline Unclassified & & & & & 2 & 2 & $0 \%$ \\
\hline Business & & & & 1 & & 1 & $0 \%$ \\
\hline Gen Studies & & & & & & 0 & \\
\hline LA & & & & & & 0 & \\
\hline Healthcare & & 1 & 1 & & & 2 & $100 \%$ \\
\hline
\end{tabular}

Table 7 Persistence of EST104 Students from spring 2012 through February, 2013

Table 7 shows that the persistence and Success Rates of students enrolled in EST104 in the spring of 2012 were nearly as impressive as those of the EST104 students from the fall of 2011. An examination of the transcripts of the two suspended students showed that once again each was so poorly prepared that they could not be formally accepted into the Engineering Science program, but as Unclassified were still allowed by an advisor to enroll in EST104. Once again, the Unclassified students failed EST104 and were subsequently suspended.

\begin{tabular}{|c|c|c|c|c|c|c|c|}
\hline \multicolumn{7}{|c|}{ Status (as of February, 2013) of students receiving grade in EST104 in Fall, 2012} & $\begin{array}{l}\text { Success } \\
\text { Rate }\end{array}$ \\
\hline Major & $\begin{array}{l}\text { Rcvd } \\
\text { Degree }\end{array}$ & $\begin{array}{l}\text { Still at } \\
\text { NECC }\end{array}$ & $\begin{array}{l}\text { Left in Good } \\
\text { Standing }\end{array}$ & $\begin{array}{l}\text { Left on } \\
\text { Probation }\end{array}$ & $\begin{array}{l}\text { Left } \\
\text { Suspended }\end{array}$ & Total & \\
\hline ES & 2 & 40 & 2 & $\mathbf{2}$ & & 46 & $96 \%$ \\
\hline ET & 1 & 3 & & & & 4 & $100 \%$ \\
\hline CIS & & 2 & & & & 2 & $100 \%$ \\
\hline Unclassified & & & & & 1 & 1 & $0 \%$ \\
\hline Business & & & & & 3 & 3 & $0 \%$ \\
\hline Gen Studies & & & & & & 0 & \\
\hline LA & & 1 & & & & 1 & $100 \%$ \\
\hline Healthcare & & & & & & 0 & \\
\hline
\end{tabular}

Table 8 Persistence of EST104 Students from fall 2012 through February, 2013

Table 8 shows that the persistence and Success Rates of students enrolled in EST104 in the fall of 2012 were again as impressive as those of the EST104 students from the fall of 2011 and the spring of 2012. Also, the number of Unclassified Students enrolling in EST104, failing, and then being suspended had now shrunk to one. 


\section{Pre- and Post-Activities Self-Assessment of Skills in EST104 for fall 2011}

In 2011-2012, Paula Leventman, an outside evaluator, was employed to evaluate the EST104 course. Under her direction, thirty students enrolled in EST104 in fall of 2011 completed an anonymous pre-EST104 survey and twenty-nine of the thirty completed a post-survey. A selfcreated ID composed of the first two letters of their mother's birth name and the last two digits of their social security number was used to match up pre and post response. Table 4 summarizes their pre- and post-self assessments ${ }^{7}$.

\begin{tabular}{|c|c|c|c|c|}
\hline & & $\begin{array}{l}\text { Very poor \& } \\
\text { Poor }\end{array}$ & Fair & $\begin{array}{l}\text { Good \& } \\
\text { Excellent }\end{array}$ \\
\hline \multirow{2}{*}{ Programming } & Pre & 58 & 25 & 17 \\
\hline & Post & 10 & 31 & 59 \\
\hline \multirow{2}{*}{ Problem solving } & Pre & 6 & 24 & 70 \\
\hline & Post & 3 & 29 & 69 \\
\hline \multirow{2}{*}{ Debugging } & Pre & 53 & 23 & 24 \\
\hline & Post & 17 & 38 & 45 \\
\hline \multirow{2}{*}{ Experimental application } & Pre & 37 & 50 & 13 \\
\hline & Post & 10 & 24 & 66 \\
\hline \multirow{2}{*}{ Writing software } & Pre & 72 & 25 & 3 \\
\hline & Post & 17 & 33 & 51 \\
\hline \multirow{2}{*}{$\begin{array}{l}\text { Electronic components \& } \\
\text { circuits }\end{array}$} & Pre & 46 & 38 & 16 \\
\hline & Post & 17 & 31 & 52 \\
\hline \multirow{2}{*}{ Reading schematics } & Pre & 31 & 52 & 17 \\
\hline & Post & 10 & 31 & 59 \\
\hline \multirow{2}{*}{ Thinking logically } & Pre & 6 & 18 & 76 \\
\hline & Post & 0 & 7 & 93 \\
\hline
\end{tabular}

Table 6: Pre- and Post-Projects Self-Assessment of Skills in EST104*

*Numbers represent percentage of class with given response. The number of respondents was 30 for the "Pre" survey and 29 for the "Post" survey. 
Dr. Leventman in her report ${ }^{7}$ of December 2011 concluded:

1. There is no doubt that the [project] elements were very effective as presented in the [community college's] Engineering Essentials and Design course in fall 2011.

2. There was marked improvement in every skill and knowledge area, as all of the data clearly indicates.

3. Students brought varied backgrounds in mathematics and highly varied programming skills to this class. Nonetheless, the feeling of success and accomplishment as expressed by 18 of 29 respondents is impressive.

\section{Post-Activities Self-Assessment of Skills in EST104 for spring 2012}

At the conclusion of the spring 2012 semester, the same outside evaluator looked at post-EST104 self-assessments by the students who enrolled in EST104 for the spring and declared that "The post-program self assessments of students were impressive. “ 8

Table 7 from Dr. Leventman's report ${ }^{8}$ compares the post-project self-assessment of skills in EST104 for fall of 2011 and spring of 2012. Numbers in the table represent percentages of responses, not the actual number of responses.

\begin{tabular}{|c|c|c|c|c|}
\hline & & $\begin{array}{l}\text { Very poor \& } \\
\text { poor }\end{array}$ & Fair & $\begin{array}{l}\text { Good \& } \\
\text { Excellent }\end{array}$ \\
\hline \multirow[t]{2}{*}{ Programming } & Fall & 10 & 31 & 59 \\
\hline & Spring & 8 & 42 & 50 \\
\hline \multirow[t]{2}{*}{ Problem solving } & Fall & 3 & 29 & 69 \\
\hline & Spring & $\mathbf{0}$ & 12 & 88 \\
\hline \multirow[t]{2}{*}{ Debugging } & Fall & 17 & 38 & 45 \\
\hline & Spring & 12 & 25 & 63 \\
\hline \multirow[t]{2}{*}{ Experimental application } & Fall & 10 & 24 & 66 \\
\hline & Spring & 9 & 22 & 69 \\
\hline \multirow[t]{2}{*}{ Writing software } & Fall & 17 & 33 & 51 \\
\hline & Spring & 12 & 38 & $\mathbf{5 0}$ \\
\hline $\begin{array}{l}\text { Electronic components \& } \\
\text { circuits }\end{array}$ & $\begin{array}{l}\text { Fall } \\
\text { Spring }\end{array}$ & $\begin{array}{l}17 \\
21\end{array}$ & 31 & $\begin{array}{l}52 \\
62\end{array}$ \\
\hline Reading schematics & $\begin{array}{l}\text { Fall } \\
\text { Spring }\end{array}$ & $\begin{array}{l}10 \\
8\end{array}$ & 31 & $\begin{array}{l}59 \\
63\end{array}$ \\
\hline Thinking logically & $\begin{array}{l}\text { Fall } \\
\text { Spring }\end{array}$ & $\begin{array}{l}0 \\
\mathbf{0}\end{array}$ & $\begin{array}{r}7 \\
12 \\
\end{array}$ & $\begin{array}{l}93 \\
88 \\
\end{array}$ \\
\hline
\end{tabular}

Table 7 Comparison of Post-EST104 Self Assessments for fall 2011 and spring 2012 


\section{Further Modifications}

In the Spring of 2013, two sections were offered during the day, one a hybrid section that meets on Thursdays from 2-4 pm in the lab for the project portion of the course and the other a webcompanion section which meets for four academic hours on Fridays from 10 am-1:45 pm just like the seven previous sections described in this paper. Both of these sections are being taught by Professor Pelletier. In an attempt to see if the amount of face-to-face time could be reduced and still maintain quality, a hybrid version of EST104 was developed by Professor Pelletier during the fall of 2012 for delivery during the spring. As a hybrid course, most of the work will be done by students outside of class with just two hours of face-to-face interaction with the instructor during lab time. The web-companion version will continue to be conducted in the same manner as were the first seven offerings of EST104 which have been described in this paper.

A third section of the course was offered in the evening program on Monday nights. It was taught by another adjunct professor who had attended the same two-week faculty development workshops as the principal author and who attended every meeting of the Thursday section of EST104 that was taught during the fall 2012 semester.

For all three of these sections, the department, the division, and the Academic Vice-President committed to providing Supplemental Instruction (SI) with funding provided by Raytheon. The experienced SI leader of the fall of 2012 Thursday section agreed to be the SI leader of the spring Monday evening section.

Two additional SI leaders were sought, but only one was available so he volunteered to open his SI session on Wednesday afternoon to students from any of the three sections offered. These additional SI sessions for the students, led by the SI leader, are held in the lab with the equipment (stepper-motor rotors and spectrometers) that is used during the regularly scheduled class meetings.

\section{Future Directions}

Supplemental Instruction will be provided for each of three sections of this course in Fall 2013.

The hybrid version of this course will be carefully evaluated after the spring 2013 semester concludes to see if it should be continued in the spring of 2014. A hybrid version will not be offered in the fall of 2013 to allow sufficient time to study the hybrid version of spring of 2013.

There is an additional module that was developed over the last three years that is not yet in use at NECC and there is also an extension of one activity that is part of the present EST104 course. The NECC faculty would like to integrate both into the course next year.

Already the student skills in MATLAB programming are being used in some of the Math courses at the college. The Engineering Science faculty will encourage more of the Math Department faculty to employ MATLAB in their courses for the engineers. 
In addition to assessing the hybrid version of the existing EST104 course, the Engineering Science faculty at NECC will want to look at the continuing education version which is being offered in the evening for the first time in the spring 2013 semester, to see if this version is as successful as the web-enhanced version offered during the day which is the subject of this paper.

The student success rates and the course completion rates for EST104 should be evaluated after the spring 2013 semester concludes to ensure that these rates remain high.

The experience of NECC graduates transferring to bachelor degree programs will be monitored to ensure that NECC graduates are sufficiently conversant in MATLAB to succeed at the fouryear colleges to which they transfer.

\section{Conclusions}

Course Completion Rates and Student Success Rates remain high for this course.

The Engineering Science faculty members remain enthusiastic about the course as do the students and the NECC Advising Center.

The project-based nature of this course and the emphasis on MATLAB programming applied to real science and technology projects are strengths and will be continued. 


\section{Bibliography}

1. Phase 1 Report, Creating a Culture for Scholarly and Systemic Innovation in Engineering Education.

Washington, D.C.: American Society for Engineering Education, June 2009.

$\leq$ http://www.asee.org/about-us/the-organization/advisory-

committees/CCSSIE/CCSSIEE_Phase1Report_June2009.pdf $>$.

2. Piechota, Thomas C. et al, Project-Based Learning in a Freshman Engineering Course: University - High School Partnership. Las Vegas, Nevada, 2003.

< http://faculty.unlv.edu/piechota/proceedings/piechota-asee-psw-2003.pdf $>$

3. Bransford, John D., Ann L.Brown, and Rodney R.Cocking, editors. How People Learn: Brain, Mind, Experience, and School: Expanded Edition. Committee on Developments in the Science of Learning, National Academy Press, Washington, D.C. 2000.

4. National Research Council, National Science Education Standards, National Academy Press, Washington, DC (1996).

5. McKnight, Stephen W., Michael E. Pelletier, and Paula Leventman. AC 2012-3794: A First-Year "Introduction To Engineering" Course at a Community College Using Hands-On MATLAB Experiment Control. Proceedings of the 2012 ASEE Annual Conference and Exposition, San Antonio, Texas (2012).

6. Fallon, Thomas. "Re: Can we show that EST104 Engineering Essentials and Design is a success? Message to Michael Pelletier. February 28, 2013. E-mail.

7. Leventman, Paula. Pre and Post Program Students Self Assessments, Boston, MA, December 2011.

8. Leventman, Paula. Post-Program Self Assessment Spring 2012, Boston, MA, May 2012. 